\title{
REVIEW \\ George Faithful \\ Mothering the Fatherland: \\ A Protestant Sisterhood Repents for the Holocaust
}

(Oxford: Oxford University Press, 2014), hardcover, xvii $+270 \mathrm{pp}$.

Christopher J. Probst, Washington University in St. Louis

Mothering the Fatherland is a focused and sympathetic study of the life and work of a unique group of women who were so haunted by the Holocaust that, in the wake of the Second World War, they formed a Protestant sisterhood focused on intercessory repentance by the "true" Christians of Germany for the sins committed by the nation during the Third Reich. It is an absorbing work of historical theology that is especially significant for the effective manner in which the author situates the theology and practice of the sisterhood in their historical and intellectual contexts and for the author's thoughtful analysis of the theology of the sisterhood's co-founder.

George Faithful argues that the Ecumenical Sisterhood of Mary (Ökumenische Marienschwesternschaft), which was founded in 1947 by Klara Schlink (later Mother Basilea) and Erika Madauss (later Mother Martyria), sought to prevent via intercessory prayer the judgment of God on Germany, which both believed would come unless the nation repented for its sins, chief of which was its involvement in the Holocaust. The idea that Germans, much less Protestant Germans, should repent for the Shoah, was not widely shared in the early post-war era. This fact alone makes the sisterhood a fascinating case study. That the sisterhood also exhibited affinities with elements of German Pietism and (later) with the Charismatic movement enhances the curiosity all the more. 
As Faithful recognizes, many Protestants held views that were consonant with some crucial aspects of Nazi ideology, including ardent nationalism and antisemitism. During the Third Reich, a substantial, outspoken minority of Protestants avidly and openly supported the Nazis in their reprehensible goals concerning the Jewish Question. Even so, open resistance to Nazism and secret assistance for Jews living under Nazi oppression and threat of murder were found among small groups of German Protestants. The "Büro Grüber" (Grüber Office), based in Berlin, provided Jews (including Jews who converted to Christianity) who were under dire threat from the Reich with advice about emigration, finding employment abroad, social assistance, legal matters, and educational support. For example, in Württemberg (in southwest Germany), a group of pastors and parishioners sheltered at least seventeen Jewish refugees in sixty church parsonages in a so-called "Rectory Chain.”

Though Schlink published numerous theological works after the war, including books that emphasized the collective guilt of the German nation for the Holocaust, she does not seem to have viewed her work as part of a broader theological discussion that might have included participants in such war-time Protestant rescue groups. Despite their differences, where the Holocaust and Jewish-Christian relations is concerned, there is a congruence of views between groups such as the Büro Grüber, the Württemberg rectory chain, and the sisterhood. A comparative scholarly study of such groups would be welcome.

The most intriguing chapter of the book is titled "Schlink's Pseudo-Judaic, Germanic Vision of Nationhood," in which Faithful examines, among other things, Schlink's theological outlook on peoples (Völker), in particular "Germans" and "Jews." Faithful finds that Schlink's views of peoples, nations, and ethnicities were derived in the main from the Hebrew Bible and from (chiefly nineteenth and twentieth century) German views of nationalism. Ironically, for Schlink, Faithful writes, "To be a Jew was to be a member of a God-ordained, 
uniquely blessed people whose long centuries of suffering were over. To be a German was to be a self-professed Christian and a Gentile. For Schlink, Jew and German were two mutually exclusive categories, and this, more than any of her ideas, resonated with the worldview of the German nationalists. ... That Schlink so comprehensively inverted which pole was positive, elevating the Jewish people to a status above what even many German nationalists had claimed for Germany, marks her thought as definitively anti-Nazi” (p. 132). Faithful highlights here incisively some of the ironies inherent in the thought of a remarkably unique woman-a philosemitic, antiNazi theologian and Protestant nun.

On occasion, the main argument is hampered by assertions that are a bit too tentative. Yet, this is mitigated by succinct chapter conclusions and helpful sub-headings within chapters, both of which make the book very readable. Mothering the Fatherland will be of interest to anyone engaged in the study of the Holocaust, twentieth-century German Protestantism, Jewish-Christian relations, and, more broadly, historical theology in the modern era. Caveats aside, this work substantially deepens our knowledge of a previously unknown and fascinating corner of German Protestantism. 